\title{
Effect of $\mathrm{CaF}_{2}$ on the Viscosity and Microstructure of $\mathrm{CaO}-\mathrm{SiO}_{2}-\mathrm{Al}_{2} \mathrm{O}_{3}$ Based Continuous Casting Mold Flux
}

\author{
Xingjuan Wang ${ }^{1,2, *}$, Hebin Jin ${ }^{1,2}$, Liguang Zhu ${ }^{3, *}$, Ying $\mathrm{Xu}^{2}$, Ran Liu ${ }^{1}$, Zhanlong Piao ${ }^{2}$ and \\ Shuo $\mathrm{Qu}^{1,2}$ \\ 1 College of Matallurgy and Energy, North China University of Science and Technology, \\ Tangshan 063000, China \\ 2 Hebei Engineering Research Center of High Quality Steel Continuous Casting, Tangshan 063000, China \\ 3 School of Materials Science and Engineering, Hebei University of Science and Technology, \\ Shijiazhuang 050018, China \\ * Correspondence: wxingjuan@ncst.edu.cn (X.W.); zhuliguang@ncst.edu.cn (L.Z.); \\ Tel.: +86-189-3157-1093 (X.W.); +86-311-8166-8002 (L.Z.)
}

Received: 10 June 2019; Accepted: 5 August 2019; Published: 8 August 2019

\begin{abstract}
In this study, a $\mathrm{CaO}-\mathrm{SiO}_{2}-\mathrm{Al}_{2} \mathrm{O}_{3}$-based continuous casting mold flux was designed using the FactSage thermodynamics software to determine the composition range of $\mathrm{CaF}_{2}$. The viscosity characteristics of the mold flux were determined using a rotating viscometer. The results show that the constant temperature viscosity at $1300{ }^{\circ} \mathrm{C}$ decreases gradually as $\mathrm{CaF}_{2}$ content is increased from $3 \%$ to $11 \%$ in the $\mathrm{CaO}-\mathrm{SiO}_{2}-\mathrm{Al}_{2} \mathrm{O}_{3}$-based slag. Viscosity is reduced from 0.854 to $0.241 \mathrm{~Pa} \cdot \mathrm{s}$, viscous the flow activation energy is reduced from 157.74 to $114.34 \mathrm{~kJ} \cdot \mathrm{mol}^{-1}$, and the break temperature is reduced from 1280 to $1180{ }^{\circ} \mathrm{C}$. Furthermore, when the $\mathrm{CaF}_{2}$ content is increased from $3 \%$ to $11 \%$, the number of nonbridging fluorine bonds (Al-F structure and Si-F structure) in the melt increases to 287, the number of bridging fluorine bonds (Al-F-Al structure, $\mathrm{Si}-\mathrm{F}-\mathrm{Si}$ structure, and $\mathrm{Si}-\mathrm{F}-\mathrm{Si}$ structure) is only 17, and the network rupture of fluorine ions in the system is larger than the network formation. Consequently, both the degree of polymerization and viscosity are reduced.
\end{abstract}

Keywords: fluorine; mold flux; viscosity; microstructure; continuous casting

\section{Introduction}

The main component of fluorite is $\mathrm{CaF}_{2}$, which is added as an auxiliary material in the steel continuous casting production to improve the lubrication and partial heat transfer between a crystallizer and a solidified shell [1,2]. Fluorite used in metallurgical industry accounts for $25 \%$ of the total output of fluorite. Fluoride has different degrees of evaporation under high temperature conditions, which does extremely harmful to the environment, people and equipment $[3,4]$. However, it is also a scarce strategic resource. According to statistics, the total global fluorite reserves are 470 million tons. The fluorite resources in the United States and Western Europe have been exhausted. In addition, China has stopped issuing new fluorite licenses since 2003 to protect fluorite resources. The National Mineral Resources Planning (2016-2020) issued by the Ministry of Land and Resources in 2016 officially listed fluorite as a national strategic mineral resource. Therefore, to reduce the consumption of fluorite, it is necessary to study the occurrence of fluorine in a continuous casting mold flux and develop the development of a fluorine-free mold flux, which plays an important role in resource control.

Park and Ueda et al. [5-7] found that $\mathrm{F}$ ions act as depolymerized bridging oxygen $\left(\mathrm{O}^{0}\right)$ and nonbridging oxygen $\left(\mathrm{O}^{1}\right)$ in silicates, and the reaction relationship is as shown in Equations (1) and (2). 


$$
\begin{gathered}
{\left[\mathrm{Si}_{3} \mathrm{O}_{9}\right]^{6-}+2 \mathrm{~F}^{-}=\left[\mathrm{Si}_{2} \mathrm{O}_{6} \mathrm{~F}\right]^{5-}+\left[\mathrm{SiO}_{3} \mathrm{~F}\right]^{3-}} \\
{\left[\mathrm{Si}_{2} \mathrm{O}_{6} \mathrm{~F}\right]^{5-}+\left[\mathrm{SiO}_{3} \mathrm{~F}\right]^{3-}+2 \mathrm{~F}^{-}=2\left[\mathrm{SiO}_{3} \mathrm{~F}\right]^{3-}+\left[\mathrm{SiO}_{2} \mathrm{~F}_{2}\right]^{2-}+\mathrm{O}^{2-}}
\end{gathered}
$$

Kim et al. [8] used X-ray photoelectron spectroscopy to study the effect of the addition of $\mathrm{CaF}_{2}$ in a $\mathrm{CaO}-\mathrm{SiO}_{2}-\mathrm{Na}_{2} \mathrm{O}$ slag system on slag viscosity and slag structure. Asada et al. [9] studied the slag structure of a molten $\mathrm{CaO}-\mathrm{CaF}_{2}-\mathrm{SiO}_{2}$ slag system and pointed out that substituting $\mathrm{CaO}$ with $\mathrm{CaF}_{2}$ enhanced the polymerization reaction. However, owing to the increase in fluorine ions, the polymerization was suppressed to replace the position of $\mathrm{Si}-\mathrm{O}$ tetrahedral oxygen, and the number of $\mathrm{Q}_{3}$ and $\mathrm{Q}_{4}$ was reduced. Gao et al. [10] used Raman spectroscopy to determine the effect of fluorine on the structure of a $\mathrm{CaO}-\mathrm{SiO}_{2}-\mathrm{Al}_{2} \mathrm{O}_{3}-\mathrm{Na}_{2} \mathrm{O}-\mathrm{CaF}_{2}$ continuous casting mold flux and reported that the number of nonbridging oxygen ions in $\mathrm{Si}-\mathrm{O}$ and $\mathrm{Al}-\mathrm{O}$ tetrahedra increased and the degree of polymerization decreased. Yan et al. [11] studied the feasibility of using $\mathrm{CaO}-\mathrm{Al}_{2} \mathrm{O}_{3}$-based slag to replace $\mathrm{CaF}_{2}$ with $\mathrm{B}_{2} \mathrm{O}_{3}$ and found that $\mathrm{B}_{2} \mathrm{O}_{3}$ can inhibit crystallization and control heat transfer. Sasaki et al. [12] studied a $\mathrm{Na}_{2} \mathrm{O}-\mathrm{NaF}-\mathrm{SiO}_{2}$ slag system using Raman spectroscopy and a molecular dynamics model. They found that a Si-F bond was not formed in the slag system and believed that the fluorine ion mainly matched with the $\mathrm{Na}$ ion. Vincent et al. [13] reported that the radius of the fluoride ion was smaller than that of the oxygen ion. Moreover, the fluorine ion had a higher mobility, and the system depolymerization reaction was larger. Hayashi et al. [14] reported that the fluorine was dominantly coordinated with $\mathrm{Ca}$ rather than $\mathrm{Si}$, and the degree of polymerization did not change with $\mathrm{CaF}_{2}$ addition in constant alkalinity. Niu et al. [15] studied the change in the characteristic spectrum of cuspidine $\left(3 \mathrm{CaO} \cdot 2 \mathrm{SiO}_{2} \cdot \mathrm{CaF}_{2}\right)$ using high temperature Raman spectroscopy and pointed out that, as temperature increased, system disorder increased, the high frequency peak broadened, and the crystal lost its long-range orderliness. When cuspidine was melted, the structure of dimmer $\mathrm{Q}_{1}$ was still dominant in the melt. Additionally, the structure monomer $\mathrm{Q}_{0}$ was correspondingly increased, and the peripheral structure was relaxed. Wang et al. [16] studied the crystallization behavior of protective slag in a $\mathrm{CaO}-\mathrm{SiO}_{2}-\mathrm{Al}_{2} \mathrm{O}_{3}$ slag system in $\mathrm{CaF}_{2}$ and pointed out that after the mass fraction of $\mathrm{CaF}_{2}$ was increased to a specific amount, the fluorine ion was converted to a certain degree due to the network forming effect. Wu [17] found through molecular dynamics studies that the average bond length of $\mathrm{Al}-\mathrm{O}, \mathrm{Ca}-\mathrm{O}$ and $\mathrm{Ca}-\mathrm{F}$ increased. Furthermore, the average bond length of a small number of $\mathrm{Al}-\mathrm{F}$ and $\mathrm{Si}-\mathrm{F}$ bonds decreased and the fluorine ion replaced the oxygen ions, which affected the melt structure. Previous studies have been conducted on the influence of fluorine on the metallurgical properties of a mold flux. However, the state of the occurrence of fluorine in a high temperature mold flux is still unclear. The metallurgical properties of a mold flux are determined by its structure. Composition determines structure, and structure determines performance. Thus, it is necessary to study the structure of a mold flux.

In this study, a $\mathrm{CaO}-\mathrm{SiO}_{2}-\mathrm{Al}_{2} \mathrm{O}_{3}$-based mold flux was designed using the FactSage thermodynamics software to determine the composition range of $\mathrm{CaF}_{2}$. The viscosity characteristics of the mold flux were determined by utilizing a rotating viscometer. The Scigress molecular dynamics software was used to calculate the radial distribution function, coordination number function, and fluorine microstructure of a $\mathrm{CaO}-\mathrm{SiO}_{2}-\mathrm{Al}_{2} \mathrm{O}_{3}-\mathrm{CaF}_{2}$-based continuous casting mold flux. The results can provide a theoretical basis for developing a fluorine-free mold flux and for seeking out suitable fluorine substitutes. Now that we understand the microstructure of fluorine, we can use molecular dynamics to explore the microcosmic aspects of combinations of alternatives to fluorine that are composed of one or more elements.

\section{Calculation and Experimental Procedures}

\subsection{Selection Principle of $\mathrm{CaF}_{2}$ Content}

To macroscopically determine the effect of $\mathrm{CaF}_{2}$ on the $\mathrm{CaO}-\mathrm{SiO}_{2}-\mathrm{Al}_{2} \mathrm{O}_{3}$-based slag system, a phase diagram was created using the phase diagram module of FactSage (FactSage 7.2, Thermfact/CRCT and Technologies, Canada and Germany). The three components, namely $\mathrm{CaO}, \mathrm{SiO}_{2}$, and $\mathrm{Al}_{2} \mathrm{O}_{3}$, were set as 
the main components of the phase diagram, and $\mathrm{CaF}_{2}$ was the fixed component. The phase diagram was drawn using these four components, and the influence of $\mathrm{CaF}_{2}$ on the melting temperature and liquid phase formation characteristics of the flux was analyzed. The phase diagram had a temperature range of $1100-1600{ }^{\circ} \mathrm{C}$ and a step size of $50{ }^{\circ} \mathrm{C}$. The calculation results are shown in Figure 1.

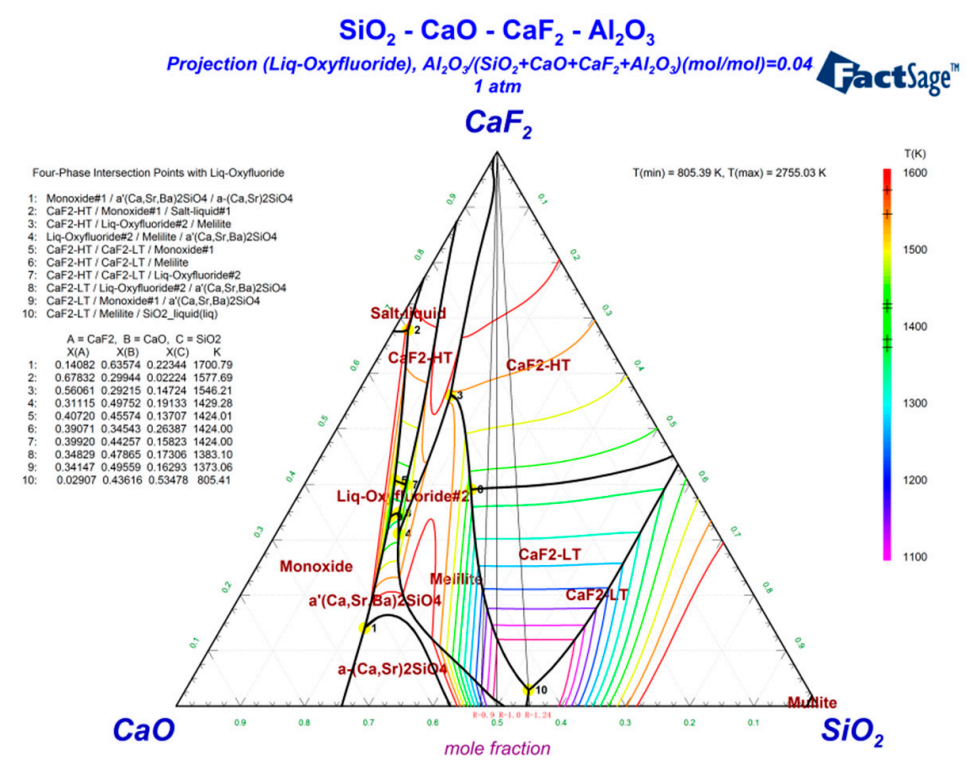

Figure 1. $\mathrm{CaO}-\mathrm{SiO}_{2}-\mathrm{Al}_{2} \mathrm{O}_{3}-\mathrm{CaF}_{2}$ quaternary phase diagram.

The casting temperature of molten steel in the continuous casting process was approximately $1550{ }^{\circ} \mathrm{C}$. The phase diagram calculated the liquid phase region of the $\mathrm{CaO}-\mathrm{SiO}_{2}-\mathrm{Al}_{2} \mathrm{O}_{3}-\mathrm{CaF}_{2}$ quaternary slag system at a temperature below $1600{ }^{\circ} \mathrm{C}$. The thin solid line in Figure 1 represents the isotherm composed of the liquidus temperature, and the area surrounded by the thick solid line represents the crystalline region of the mineral, which first crystallizes when the temperature is decreased. To achieve the melting temperature, viscosity change, and physicochemical properties of the protective slag after the adsorption of inclusions, metallurgical workers frequently control the alkalinity of the slag between 0.9 and 1.10 [18]. Therefore, it is in accordance with the requirements that alkalinity $\mathrm{R}$ was approximately 1.0. Figure 1 shows that the $\mathrm{CaF}_{2}$ content was in a range of $0-12 \%$ when $\mathrm{R}=1.0$. The liquid phase temperature in Figure 1 is $1100{ }^{\circ} \mathrm{C}$. When the $\mathrm{CaF}_{2}$ content was in a range of $11-30 \%$, the liquidus temperature was $1100{ }^{\circ} \mathrm{C}$, which gradually increased to $1350{ }^{\circ} \mathrm{C}$. Considering that the $\mathrm{CaF}_{2}$ content was in a range of $0-12 \%$, the liquid phase was stable. In addition, as $\mathrm{CaF}_{2}$ is a toxic substance, the $\mathrm{CaF}_{2}$ content of the $\mathrm{CaO}-\mathrm{SiO}_{2}-\mathrm{Al}_{2} \mathrm{O}_{3}-\mathrm{CaF}_{2}$ quaternary slag system should be controlled within $12 \%$.

\subsection{Fluorine Slag Viscosity Performance Test}

A test was conducted on a fluorine-containing protective slag of a steel plant. Cement clinker, a pre-melting material, and wollastonite were used as raw materials. $\mathrm{CaF}_{2}$ was added by chemical pure reagent. When the basicity of the mold flux was maintained, the content of $\mathrm{CaF}_{2}$ was changed. The chemical composition is presented in Table 1.

Table 1. Chemical composition of a fluorine-containing mold flux (\%).

\begin{tabular}{ccccccccccc}
\hline Component & $\mathbf{S i O}_{\mathbf{2}}$ & $\mathbf{A l}_{\mathbf{2}} \mathbf{O}_{\mathbf{3}}$ & $\mathbf{M g O}$ & $\mathbf{M n O}_{\mathbf{2}}$ & $\mathbf{F e}_{\mathbf{2}} \mathbf{O}_{\mathbf{3}}$ & $\mathbf{N a}_{\mathbf{2}} \mathbf{O}$ & $\mathbf{C a O}$ & $\mathbf{K}_{\mathbf{2}} \mathbf{O}$ & $\mathbf{C a F}_{2}$ & $\mathbf{R}$ \\
\hline Content 1 & 40.48 & 5.0 & 2.37 & 0.39 & 3.13 & 4.33 & 40.48 & 0.82 & 3 & 1.0 \\
Content 2 & 39.48 & 5.0 & 2.37 & 0.39 & 3.13 & 4.33 & 39.48 & 0.82 & 5 & 1.0 \\
Content 3 & 38.48 & 5.0 & 2.37 & 0.39 & 3.13 & 4.33 & 38.48 & 0.82 & 7 & 1.0 \\
Content 4 & 37.48 & 5.0 & 2.37 & 0.39 & 3.13 & 4.33 & 37.48 & 0.82 & 9 & 1.0 \\
Content 5 & 36.48 & 5.0 & 2.37 & 0.39 & 3.13 & 4.33 & 36.48 & 0.82 & 11 & 1.0 \\
\hline
\end{tabular}


In this study, a rotating viscometer test device (Chongqing University, Chongqing, China) was used to determine the fixed temperature viscosity and temperature change viscosity curve of the mold flux. The schematic of the test device is shown in Figure 2.

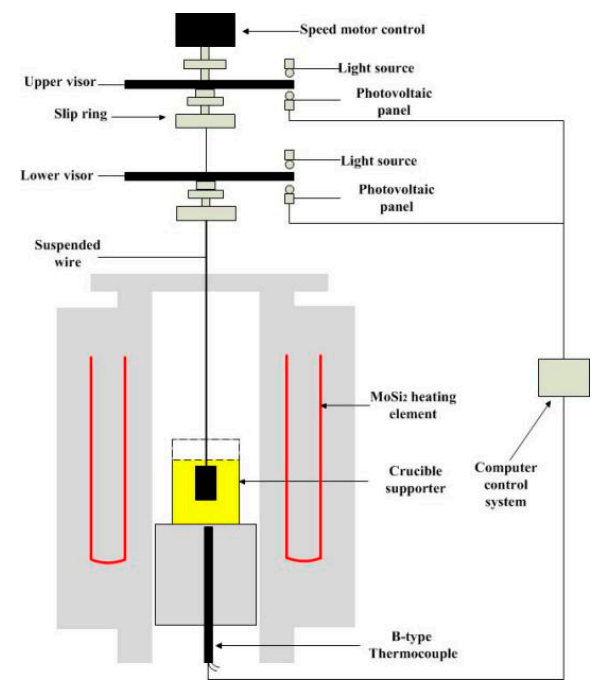

Figure 2. Schematic of viscosity measurement apparatus.

Experimental steps:

(1) First, $350 \mathrm{~g}$ of mold flux were placed into a muffle furnace. Then, the temperature of the muffle furnace was increased to $800{ }^{\circ} \mathrm{C}$ and maintained constant for $10 \mathrm{~h}$ to remove carbon from the mold residue.

(2) A graphite crucible and a sleeve were placed into the rotating viscometer, and then $350 \mathrm{~g}$ of decarburization flux were added. When the temperature of the furnace increased to $1300{ }^{\circ} \mathrm{C}$, the viscosity of the mold flux was measured at a constant temperature for $10 \mathrm{~min}$.

(3) The temperature was raised to $1400^{\circ} \mathrm{C}$ and maintained constant for $10 \mathrm{~min}$. Then, it was rapidly reduced at a rate of $5{ }^{\circ} \mathrm{C} / \mathrm{min}$, during which the viscosity at different temperatures was measured to obtain a viscosity temperature curve.

\subsection{Model Establishment}

To study the effect of a specific $\mathrm{CaF}_{2}$ content on the microstructure of the protective slag, the molecular structure of the mold flux was investigated by utilizing the Scigress (SCIGRESS, FQS Poland Sp.z.o.o, Kraków, Poland) molecular dynamics simulation method [19]. As molecular dynamics treats microscopic particles as mass points, the Newtonian motion equation of each particle was established under initial conditions and solved according to a particular time step. After several iterations, the particles in the system tended to be dynamic and stable, and the statistical particles, coordinates, system structure, and dynamic properties could be obtained. As the interaction force between particles is the result of mathematical fitting by researchers, there should not be large number of elements in the same system. In this experiment, the effect of different contents of $\mathrm{CaF}_{2}$ on the $\mathrm{CaO}-\mathrm{SiO}_{2}-\mathrm{Al}_{2} \mathrm{O}_{3}$ ternary slag system was investigated under $\mathrm{R}=1.0$. Table 2 presents the slag components used in the simulation.

The crystal structure of the mold flux changed with the composition, and the specific structure of the mold residue was not known before the simulation. The model was built by converting the existing components into specific atomic numbers and randomly adding them to a box of three-dimensional periodic boundaries. The total number of particles set by the simulation was approximately 6000 . The number of particles corresponding to each element in the simulated system was calculated from the moles ratio of each ion. Table 3 presents the number of simulated particles and the length of the side of the box. 
Table 2. Compositions of slags at $1673 \mathrm{~K}$.

\begin{tabular}{cccccc}
\hline \multirow{2}{*}{ Number } & \multirow{2}{*}{ Basicity } & \multicolumn{4}{c}{ Composition (wt \%) } \\
\cline { 3 - 6 } & & $\mathbf{C a O}$ & $\mathbf{S i O}_{\mathbf{2}}$ & $\mathbf{A l}_{\mathbf{2}} \mathbf{O}_{\mathbf{3}}$ & $\mathbf{C a F}_{\mathbf{2}}$ \\
\hline 1 & 1 & 46 & 46 & 5 & 3 \\
2 & 1 & 45 & 45 & 5 & 5 \\
3 & 1 & 44 & 44 & 5 & 7 \\
4 & 1 & 43 & 43 & 5 & 9 \\
5 & 1 & 42 & 42 & 5 & 11 \\
\hline
\end{tabular}

Table 3. Simulated atomic number and box length of slags at $1673 \mathrm{~K}$.

\begin{tabular}{|c|c|c|c|c|c|c|c|c|}
\hline \multirow{2}{*}{$\begin{array}{c}\text { Mole Fraction (\%) } \\
\mathrm{CaF}_{2}\end{array}$} & \multicolumn{6}{|c|}{ Atomic Number } & \multirow{2}{*}{$\begin{array}{c}\text { Box Length } \\
\text { (Å) }\end{array}$} & \multirow{2}{*}{$\begin{array}{r}\text { Density } \\
\left(\mathrm{g} / \mathrm{cm}^{3}\right)\end{array}$} \\
\hline & $\mathrm{Ca}$ & Si & $\mathrm{Al}$ & $\mathbf{F}$ & $\mathrm{O}$ & Total & & \\
\hline 3 & 1198 & 1070 & 137 & 106 & 3490 & 5999 & 43.345 & 2.820 \\
\hline 5 & 1213 & 1047 & 137 & 179 & 3423 & 6000 & 43.332 & 2.829 \\
\hline 7 & 1226 & 1026 & 137 & 252 & 3358 & 5999 & 43.464 & 2.838 \\
\hline 9 & 1238 & 1006 & 137 & 323 & 3295 & 5999 & 43.584 & 2.846 \\
\hline 11 & 1252 & 984 & 138 & 396 & 3229 & 5999 & 43.669 & 2.855 \\
\hline
\end{tabular}

A few necessary parameters must be set after establishing the initial model. The Born-MayerHuggins (BMH) potential function has been proven to be relatively mature in the silicate field. Potential parameters are provided in Table 4 [20,21]. The system selected the number of atoms, N; volume, V; and temperature, T. Gear's method was used for track integration, and temperature was controlled by employing the scaling method. Temperature changed with time, as shown in Figure 3. The initial temperature was set as $5000 \mathrm{~K}$ after 10,000 fs to obtain an initial configuration. Then, the temperature was decreased to $1673 \mathrm{~K}$ after $10,000 \mathrm{fs}$, and it was finally maintained at $1673 \mathrm{~K}$ at $10,000 \mathrm{fs}$ to obtain the final structure and performance information.

Table 4. Parameter values of BMH potential function.

\begin{tabular}{ccccc}
\hline Hydronium & Hydronium & $\mathbf{A}_{i j}(\mathbf{V})$ & $\mathbf{B}_{i j}(\mathbf{1} / \AA)$ & $\mathbf{C}_{i j}\left(\mathbf{e V} \cdot \AA^{\mathbf{6}}\right)$ \\
\hline $\mathrm{Ca}$ & $\mathrm{Ca}$ & $5.274 \times 10^{-21}$ & 6.25 & 4.33 \\
$\mathrm{Ca}$ & $\mathrm{O}$ & $1.150 \times 10^{-20}$ & 6.06 & 8.67 \\
$\mathrm{Ca}$ & $\mathrm{Al}$ & $5.920 \times 10^{-22}$ & 6.25 & 0 \\
$\mathrm{Ca}$ & $\mathrm{F}$ & $7.939 \times 10^{-21}$ & 6.06 & 8.67 \\
$\mathrm{Ca}$ & $\mathrm{Si}$ & $4.275 \times 10^{-22}$ & 6.25 & 0 \\
$\mathrm{Si}$ & $\mathrm{O}$ & $1.006 \times 10^{-21}$ & 6.06 & 0 \\
$\mathrm{Si}$ & $\mathrm{Si}$ & $3.466 \times 10^{-23}$ & 6.25 & 0 \\
$\mathrm{Si}$ & $\mathrm{F}$ & $6.945 \times 10^{-22}$ & 6.06 & 0 \\
$\mathrm{Si}$ & $\mathrm{Al}$ & $4.797 \times 10^{-23}$ & 6.25 & 0 \\
$\mathrm{Al}$ & $\mathrm{O}$ & $1.379 \times 10^{-21}$ & 6.06 & 0 \\
$\mathrm{Al}$ & $\mathrm{Al}$ & $6.639 \times 10^{-23}$ & 6.25 & 0 \\
$\mathrm{O}$ & $\mathrm{O}$ & $2.395 \times 10^{-20}$ & 5.88 & 17.34 \\
$\mathrm{O}$ & $\mathrm{F}$ & $1.046 \times 10^{-20}$ & 5.88 & 17.34 \\
$\mathrm{~F}$ & $\mathrm{~F}$ & $1.169 \times 10^{-20}$ & 5.88 & 17.34 \\
$\mathrm{Al}$ & $\mathrm{F}$ & $9.518 \times 10^{-22}$ & 6.06 & 0 \\
\hline
\end{tabular}




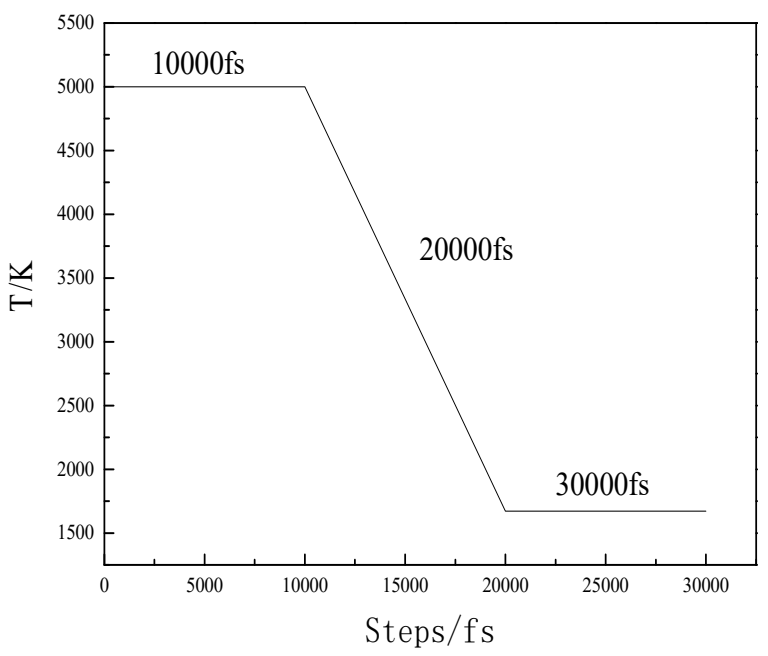

Figure 3. Variation in temperature with time.

\section{Results and Discussion}

\subsection{Flurine Slag Viscosity Performance Test and Result Analysis}

The measurement results obtained at a constant temperature of $1300{ }^{\circ} \mathrm{C}$ are shown in Figure 4 . It can be observed that as the $\mathrm{CaF}_{2}$ content increased, the fixed temperature viscosity decreased from $0.854 \mathrm{~Pa} \cdot \mathrm{s}$ at $3 \%$ to $0.241 \mathrm{~Pa} \cdot \mathrm{s}$ at $11 \%$.

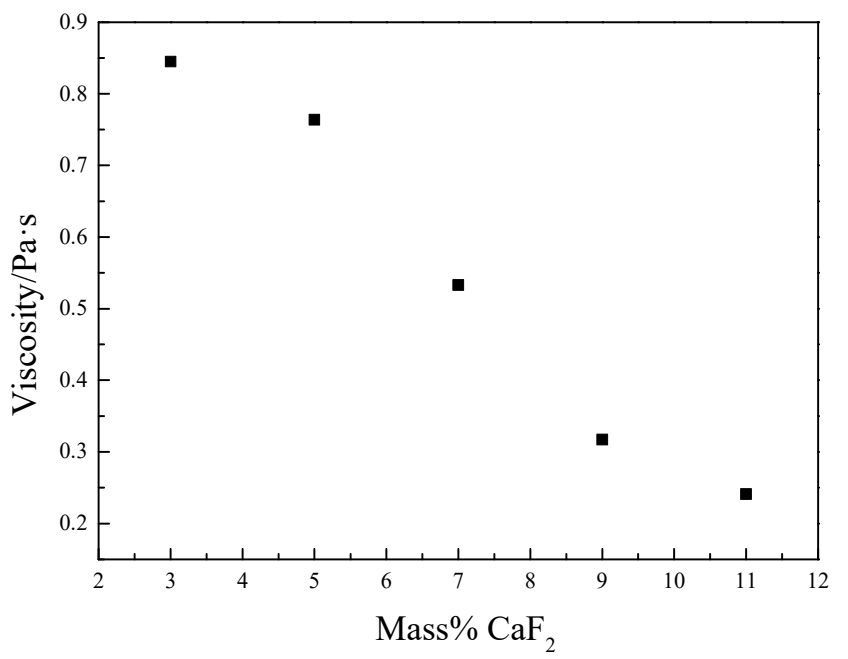

Figure 4. Influence of $\mathrm{CaF}_{2}$ content on the measured at fixed temperature of $1300{ }^{\circ} \mathrm{C}$.

Figure 5 shows the viscosity-temperature curve of the protective slag under different $\mathrm{CaF}_{2}$ contents. It can be observed that the viscosity gradually increased with the decrease in temperature. At a certain cooling rate, the point at which the viscosity changed abruptly can be referred to as the transition temperature [22]. It can be seen that as the content of $\mathrm{CaF}_{2}$ content in the mold flux increased from $3 \%$ to $11 \%$, the viscosity and transition temperature gradually decreased. The reason for the inflection point is as follows; On one hand, according to the structural theory of silicate slag, the degree of connection of the $\mathrm{Si}-\mathrm{O}$ tetrahedron network at this temperature increases rapidly, which makes viscosity increase faster. On the other hand, it is possible to precipitate crystal particles at this temperature, resulting in an increase in viscosity [23,24]. 


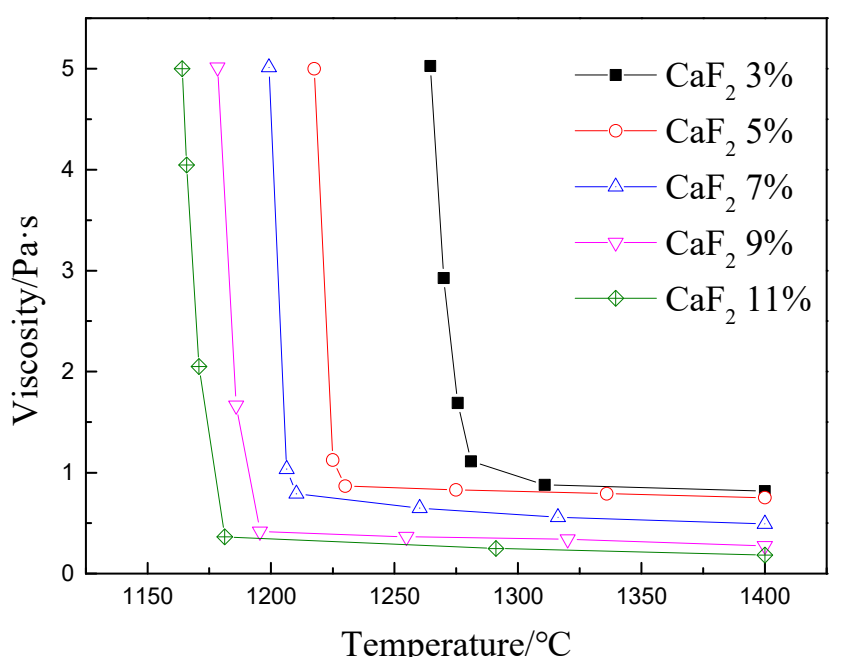

Figure 5. Viscosity temperature curve at different $\mathrm{CaF}_{2}$ contents.

Temperature is an important factor that affects the viscosity of the mold flux. The viscosity of continuous casting slag is a function of temperature. In a certain temperature range, the relationship between viscosity and temperature obeys the Arrhenius Equation (3) [25].

$$
\eta=A \exp \left[\frac{E_{\eta}}{R T}\right]
$$

where $\eta$ is the viscosity of the mold flux (Pa.s), $A$ is the frequency factor, $E_{\eta}$ is the activation energy of the viscous fluid $\left(\mathrm{J} \cdot \mathrm{mol}^{-1}\right), \mathrm{R}$ is the gas constant $\left(8.314 \mathrm{~J} \cdot \mathrm{mol}^{-1} \cdot \mathrm{K}^{-1}\right)$, and $T$ is the absolute temperature.

The viscous flow activation energy is the minimum energy required for a flow unit to overcome the barrier and transition from the original position to a neighboring cavity during flow. The viscous flow activation energy reflects the ease of flow [26-29]. Table 5 lists the viscous flow activation energy of the mold flux with different $\mathrm{CaF}_{2}$ contents.

Table 5. The effect of $\mathrm{CaF}_{2}$ on mold fluxes in activation energy and transition temperature.

\begin{tabular}{ccccc}
\hline $\begin{array}{c}\text { Mass\% } \\
\mathbf{C a F}_{\mathbf{2}}\end{array}$ & Arrhenius Equation & $\boldsymbol{E}_{\eta} /\left(\mathbf{k J} \cdot \mathbf{m o l}^{-\mathbf{1}}\right)$ & $\begin{array}{c}\text { Transition } \\
\text { Temperature }\left({ }^{\circ} \mathbf{C}\right)\end{array}$ & $\begin{array}{c}\text { Temperature } \\
\text { Range }\left({ }^{\circ} \mathbf{C}\right)\end{array}$ \\
\hline 3 & $\operatorname{Ln} \eta=18,972 / T-13.57$ & 157.74 & 1280 & $1280-1400$ \\
5 & $\operatorname{Ln} \eta=16,313 / T-13.25$ & 135.63 & 1230 & $1230-1400$ \\
7 & $\operatorname{Ln} \eta=15,813 / T-12.43$ & 131.47 & 1210 & $1210-1400$ \\
9 & $\operatorname{Ln} \eta=14,892 / T-12.42$ & 123.81 & 1195 & $1195-1400$ \\
11 & $L n=13,753 / T-12.25$ & 114.34 & 1180 & $1180-1400$ \\
\hline
\end{tabular}

It can be observed that as the $\mathrm{CaF}_{2}$ content increased, the viscous flow activation energy and transition temperature of the mold flux tended to decrease. The maximum viscous flow activation energy was $157.74 \mathrm{~kJ} \cdot \mathrm{mol}^{-1}$ at $3 \% \mathrm{CaF}_{2}$ content, and the minimum viscous flow activation energy was $114.34 \mathrm{~kJ} \cdot \mathrm{mol}^{-1}$ at $11 \% \mathrm{CaF}_{2}$. The transition temperature was reduced from 1280 to $1180{ }^{\circ} \mathrm{C}$. The activation energy of a moving particle determines the ease of slag flow. The larger the activation energy, the larger the energy required by a particle to overcome the barrier. In a silicate system, the size of the $\mathrm{Si}-\mathrm{O}$ complex ion is considerably larger than that of a metal cation, and the viscous flow activation energy required for moving in the slag is also larger. Thus, the silicate complex ion becomes a limiting factor for flow and viscosity. However, when external ions change the structure of the silicate complex ions, dissolving or polymerizing the $\mathrm{Si}-\mathrm{O}$ complex ions can cause a change the viscosity of the slag. 


\subsection{Microstructure Analysis}

Figure 6 shows the simulation results when the $\mathrm{CaF}_{2}$ content was $9 \%$ at $1673 \mathrm{~K}$. In the figure, the $\mathrm{Ca}, \mathrm{O}, \mathrm{Si}, \mathrm{Al}$, and $\mathrm{F}$ ions, are shown in blue-green, red, yellow, pink, and blue, respectively. It can be observed from Figure 6 that, in this model, the Ca ions did not participate in the bonding, the Si ions and $\mathrm{Al}$ ions existed as netting substances in the system, the $\mathrm{O}$ ions were mostly in the form of bridging and nonbridging oxygen bonds, and the F ions were mostly nonbridging fluorine bonds.

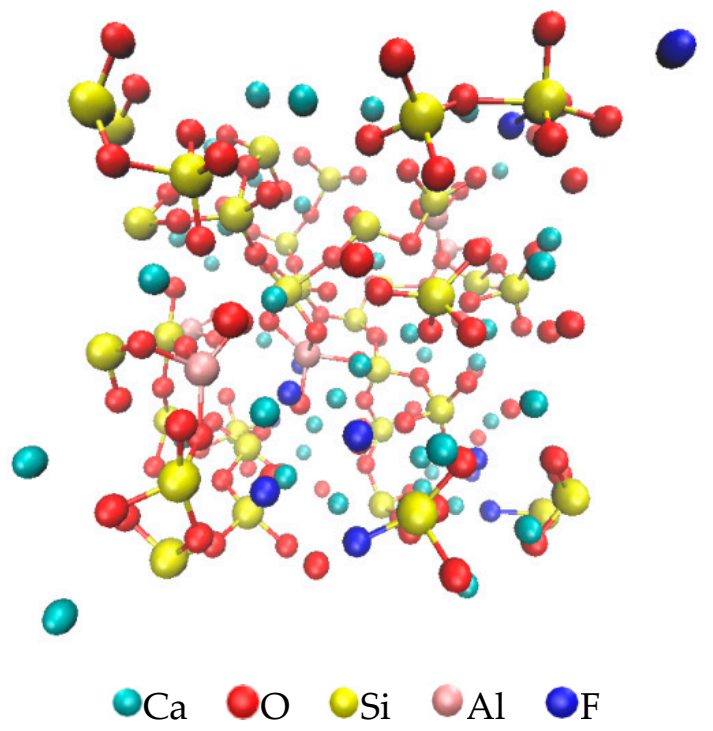

Figure 6. Model of ions in the mold flux with $9 \% \mathrm{CaF}_{2}$, obtained through simulation in Scigress.

Figure 7 shows the bonding state of the $\mathrm{F}$ ions when the content $\mathrm{CaF}_{2}$ content was $9 \%$. It can be observed that at $1673 \mathrm{~K}$, the F ions formed a bond between the $\mathrm{Al}$ ligand structure and the Si ligand structure. The fluorine bond was in the form a Si-F-Si bond, an Al-F-Al bond, and a Si-F-Al bond (structure shown in Figure 7). The bridging fluorine transformed the slag structure into a complex frame. On the contrary, the F ion and the $\mathrm{Al}$ and $\mathrm{Si}$ tetracoordinate structures formed an $\mathrm{Al}-\mathrm{F}$ bond and a Si-F bond. Furthermore, the non-bridging fluorine cluster material filled the network structure and functions to dilute the network structure. Only an extremely small number of F ions did not participate in the bonding, and they existed in the free F ion state.

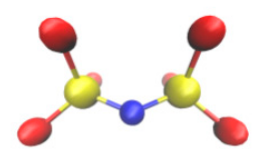

(a)

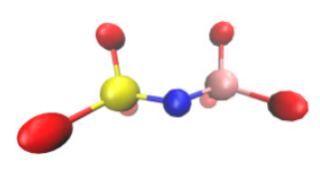

(b)

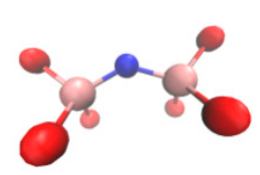

(c)

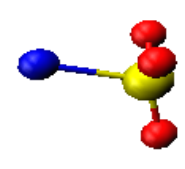

(d)

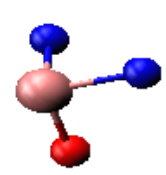

(e)

Figure 7. Bonding state diagram of the $\mathrm{F}$ ion when $\mathrm{CaF}_{2}$ content is $9 \%$ (a) $\mathrm{Si}-\mathrm{F}-\mathrm{Si}$ structure; (b) $\mathrm{Si}-\mathrm{F}-\mathrm{Al}$ structure; (c) Al-F-Al structure; (d) Al-F structure; and (e) Si-F structure.

Figure 8 shows the radial distribution function and coordination number at a $\mathrm{CaF}_{2}$ content of $9 \%$. The abscissa corresponds to the first peak of the radial distribution function [30] in Figure 8a, which is the bond length between the particles in the mold flux, and the bond lengths of $\mathrm{Si}-\mathrm{O}, \mathrm{Ca}-\mathrm{O}$, and $\mathrm{Al}-\mathrm{O}$ were $1.625,2.225$, and $1.725 \AA$, respectively. Matsui [31] conducted an X-ray diffraction experiment to determine the silicate melt structure. The bond lengths of $\mathrm{Si}-\mathrm{O}$ and $\mathrm{Al}-\mathrm{O}$ were 1.6 and $1.7 \AA$, respectively. The simulation results are consistent with those of the experiment. Figure $8 \mathrm{~b}$ shows the $\mathrm{O}$ coordination number of $\mathrm{Si}, \mathrm{Ca}$, and $\mathrm{Al}$. It can be observed from Figure $8 \mathrm{~b}$ that the coordination number of $\mathrm{Si-O}$ is 4 , and the platform was the most stable. The coordination number of Al-O was 4, 
the platform was narrower than that of $\mathrm{Si}-\mathrm{O}$, and it was the second most stable. The lack of a platform for $\mathrm{Ca}-\mathrm{O}$ indicates that the coordination number was highly unstable. Combined with the bond length of each ion pair in the simulated slag system and the full width at the half maximum of the first peak, it can be observed that the bonding ability of the $\mathrm{Si}-\mathrm{O}$ bond was the strongest and most stable, followed by $\mathrm{Al}-\mathrm{O}$. The $\mathrm{Ca}-\mathrm{O}$ bond in the slag system was the weakest and did not yield a stable structure.

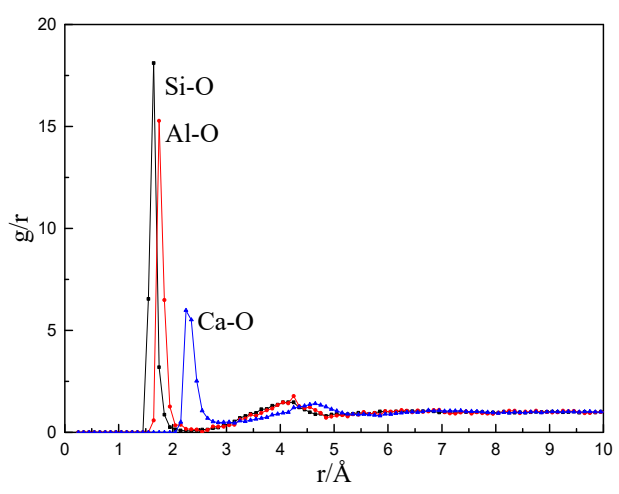

(a)

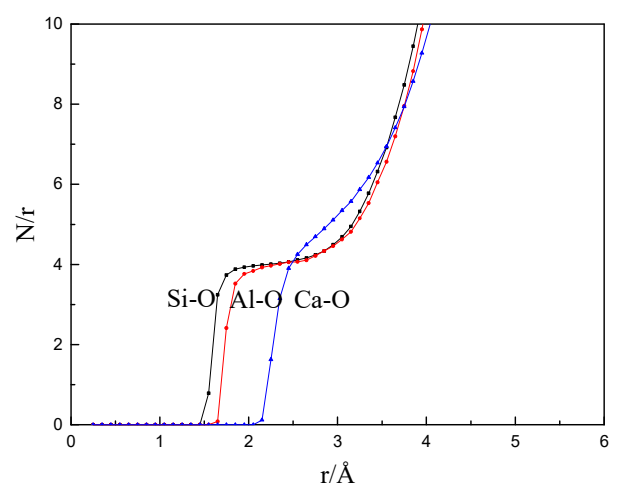

(b)

Figure 8. The simulation results of $\mathrm{CaF}_{2}$ content at $9 \%(\mathbf{a})$ radial distribution function and $(\mathbf{b})$ coordination number function.

Figure 9 shows the effect of different $\mathrm{CaF}_{2}$ contents on the $\mathrm{Si}-\mathrm{O}, \mathrm{Al}-\mathrm{O}$, and $\mathrm{Ca}-\mathrm{O}$ coordination number functions. It can be observed from Figure 9a that when the $\mathrm{CaF}_{2}$ content was increased from $3 \%$ to $11 \%$, the $\mathrm{Si}-\mathrm{O}$ coordination number "platform" of 4 was flattened, and the radius was also increased. Moreover, the formed $\mathrm{Si}-\mathrm{O}$ structure became unstable. The Al-O coordination number platform in Figure $9 \mathrm{~b}$ was similar to the $\mathrm{Si}-\mathrm{O}$ coordination number platform. Figure $9 \mathrm{c}$ shows that the $\mathrm{Ca}-\mathrm{O}$ coordination number platform did not appear when the $\mathrm{CaF}_{2}$ content was changed, indicating that $\mathrm{Ca}$ ions did not participate in bonding at $1673 \mathrm{~K}$ and they were free outside the structural system.

In Figure 10a, the coordination number of $\mathrm{Si}$ ions is shown. The coordination structures of $\mathrm{Si}-\mathrm{O}$ mainly was three coordination structures, four coordination structures, and five coordination structures. The coordination number of the other $\mathrm{O}$ atoms is too small to be listed. It can be observed that with increase in the $\mathrm{CaF}_{2}$ content, the coordination number of $\mathrm{O}$ atoms (the number of $\mathrm{Si}-\mathrm{O}$ tetrahedra) decreased, and when the content of $\mathrm{CaF}_{2}$ was more than $7 \%$, it tended to be stable. The coordination number of $\mathrm{O}$ atoms and the coordination number of 5 tended to be stable. The number of three-coordinated and five-coordinated $\mathrm{O}$ atoms was relatively small and tended to be stable.

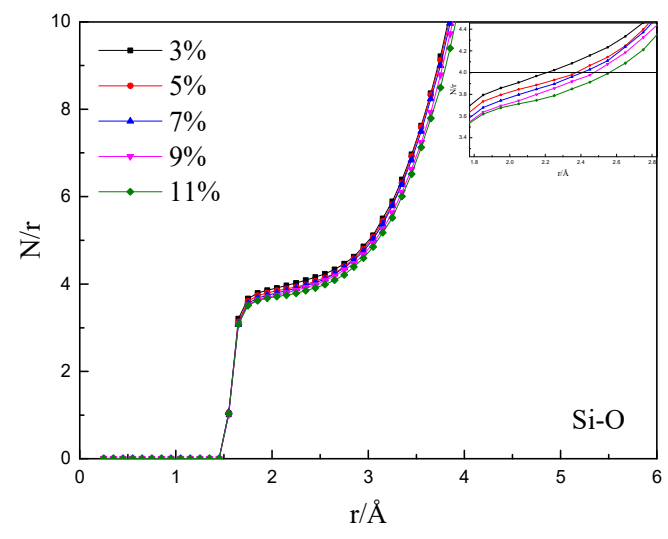

(a)

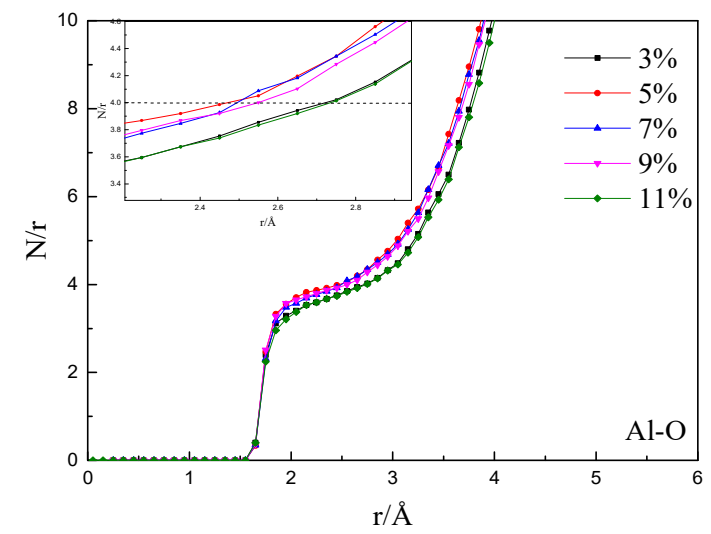

(b)

Figure 9. Cont. 


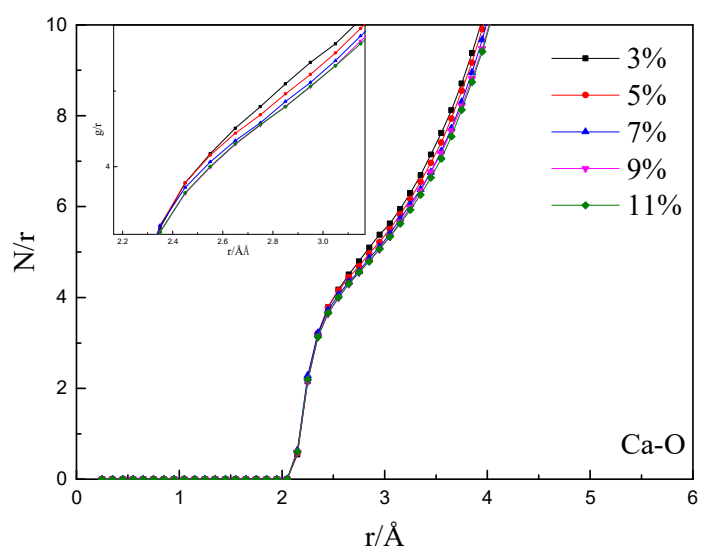

(c)

Figure 9. Coordination number function of $(\mathbf{a}) \mathrm{Si}-\mathrm{O}(\mathbf{b}) \mathrm{Al}-\mathrm{O}$ and (c) $\mathrm{Ca}-\mathrm{O}$ at different $\mathrm{CaF}_{2}$ contents.

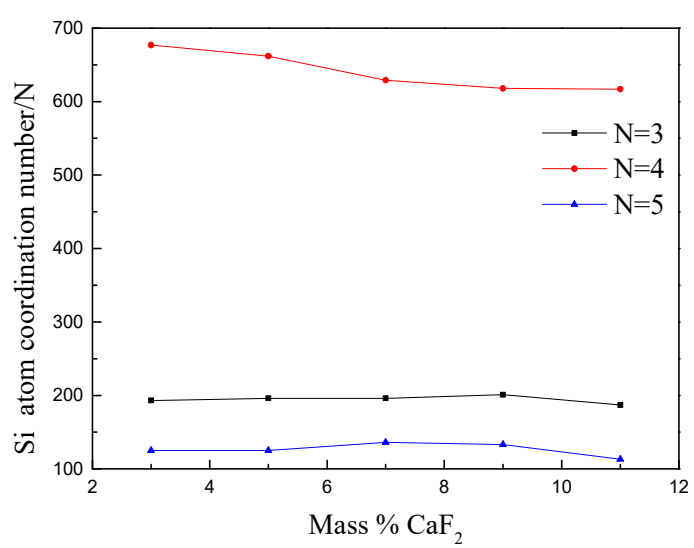

(a)

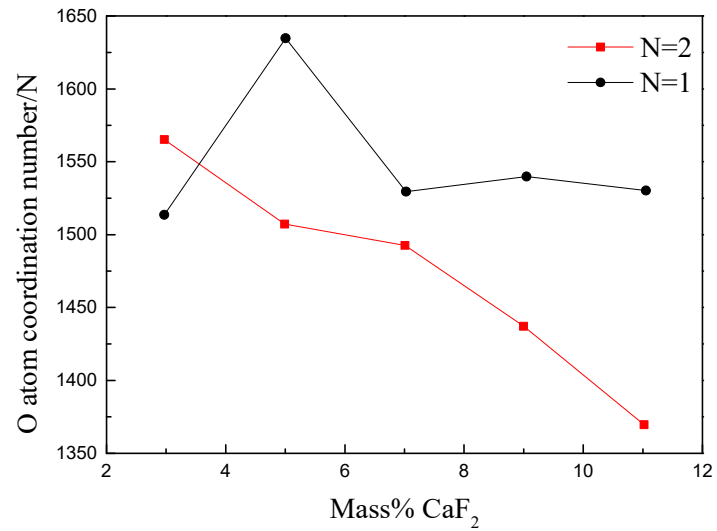

(b)

Figure 10. Number of atoms coordinated to (a) $\mathrm{Si}$ and (b) $\mathrm{O}$ at different $\mathrm{CaF}_{2}$ contents.

Figure $10 \mathrm{~b}$ shows the coordination number of the $\mathrm{O}$ ions. A two-coordinated $\mathrm{Si}$ atom with $\mathrm{O}$ atom as the center is called bridging oxygen. Nonbridging oxygen was only one-coordinated Si atom centered on the $\mathrm{O}$ atom. The network structure of the slag was mainly formed by the polymerization of silicon oxide ions. As the $\mathrm{CaF}_{2}$ content increased, the number of bridging oxygen bonds decreased, while the number of nonbridging oxygen bonds first increased, then decreases, and finally tended to be constant. The radii of $\mathrm{F}^{-}$and $\mathrm{O}^{2-}$ were $1.25 \times 10^{-7}$ and $1.32 \times 10^{-7} \mathrm{~mm}$, respectively, which were extremely close. Therefore, $\mathrm{F}^{-}$can replace $\mathrm{O}^{2-}$, and it acted on the $\mathrm{Si}-\mathrm{O}$ bond of the composite ion group to destroy the silicon oxide cluster ions. The ionic group structure split a large molecular group into smaller composite anions and gradually transformed a large-sized structural unit into a structure in which a plurality of microstructure units coexisted, thereby reducing the degree of polymerization of the protective slag. The particles flow of particles in the slag was easier, resulting in a decrease in the viscosity of the mold flux [24].

Figure 11 shows the change in the number of nonbridging fluorine bonds and bridging fluorine bonds at different $\mathrm{CaF}_{2}$ contents. The fluorine ion connecting two $\mathrm{Si}-\mathrm{O}$ structures or $\mathrm{Al}-\mathrm{O}$ structures is referred to as bridging fluorine. One end of fluorine is connected to the network structure, while the other end is not connected to network ions. The cations outside the network were used to maintain a neutral electrical value, indicating that it was nonbridging fluorine. It can be observed from Figure 11a that the number of nonbridging fluorine bonds increased from 65 to 287 with the increase in the $\mathrm{CaF}_{2}$ content. Figure $11 \mathrm{~b}$ shows that the bridging fluorine did not fluctuate significantly with the increase in the $\mathrm{CaF}_{2}$ content. The number of $\mathrm{Si}-\mathrm{F}-\mathrm{Si}$ bonds was the highest in the system; there were 
17 bonds when the $\mathrm{CaF}_{2}$ content was $7 \%$. The number of $\mathrm{Al}-\mathrm{F}-\mathrm{Si}$ bonds was the second highest; there were 7 bonds when the $\mathrm{CaF}_{2}$ content was $9 \%$. The number of $\mathrm{Al}-\mathrm{F}-\mathrm{Al}$ bonds was the lowest. The maximum number of bonds was only 2 . When the $\mathrm{CaF}_{2}$ content increased from $3 \%$ to $11 \%$, the number of nonbridging fluorine bonds was higher than that of bridging fluorine bonds. It was indicated that $\mathrm{F}$ ions can disintegrate $\mathrm{Si}-\mathrm{O}$ complex ions and $\mathrm{Al}-\mathrm{O}$ complex ions and replace $\mathrm{O}$ in $\mathrm{Si}-\mathrm{O}$ and Al-O structures, causing macromolecular groups to split into smaller Al-F, $\mathrm{Si}-\mathrm{F}, \mathrm{Si}-\mathrm{F}-\mathrm{O}$, and other structures (see Figure 12). The degree of polymerization of the mold flux and viscosity were decreased. $\mathrm{CaF}_{2}$ could combine with the high melting point oxide to form a low melting point eutectic, which is equivalent to increasing slag superheat at the same temperature. When slag superheat was increased, the number of particles with viscous flow activation energy was increased, the vibration of the particles was strengthened, the bonds between network structure were easily broken, and the complex ion was disintegrated to become a flow unit of a smaller size, thereby reducing the viscosity [32]. In summary, when the $\mathrm{CaF}_{2}$ content is within this range, fluorine ions have a stronger effect on damaging the network of the mold flux compared to forming the network.

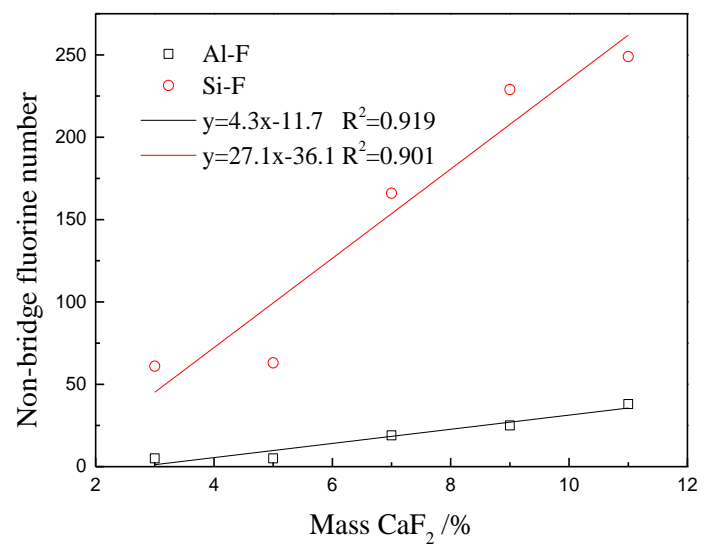

(a)

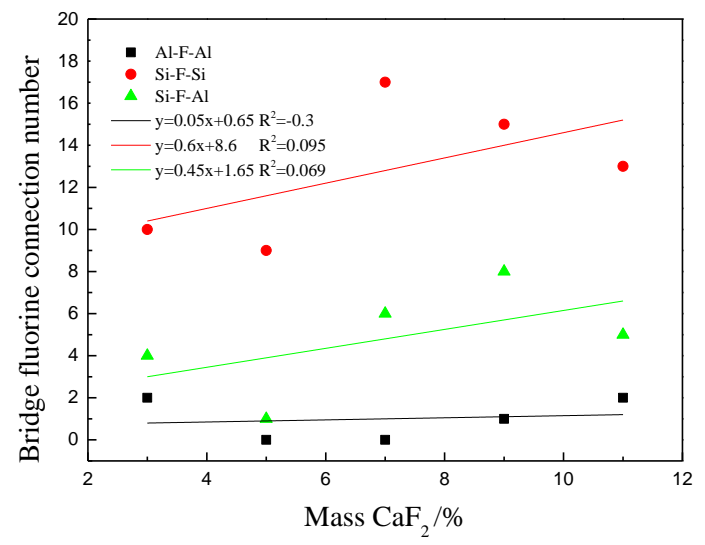

(b)

Figure 11. (a) Number of nonbridging fluorine and (b) bridging fluorine.

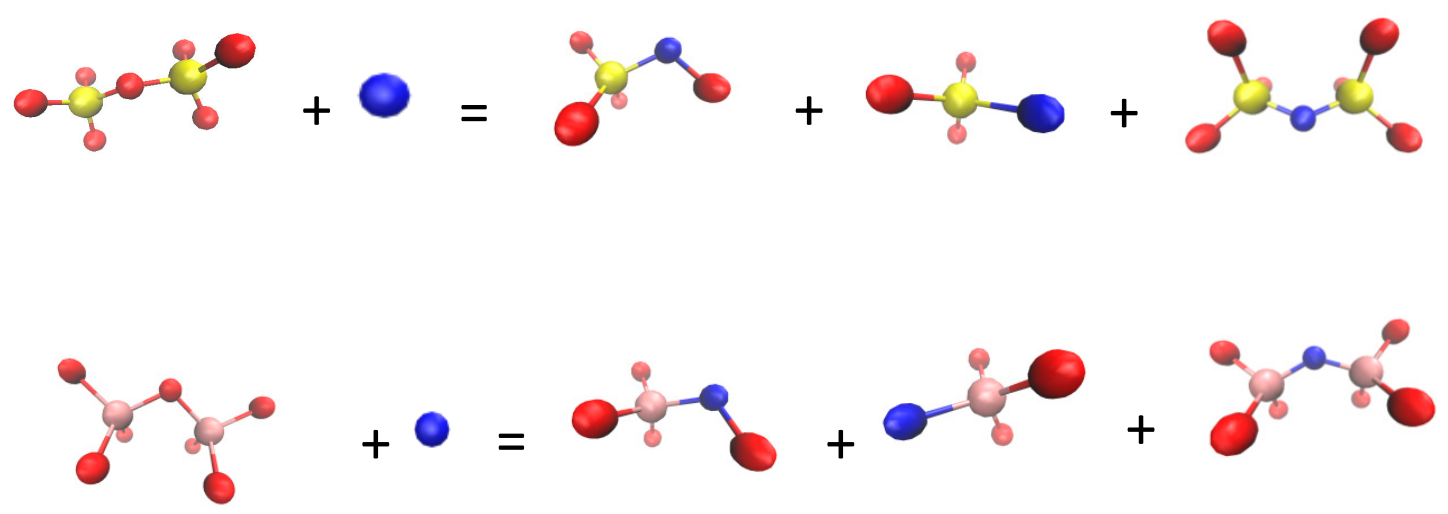

Figure 12. Disintegration of silicate and aluminate structures by fluorine ions.

\section{Conclusions}

(1) The thermodynamic calculations showed that the $\mathrm{CaF}_{2}$ content should be controlled within the range of below $12 \%$ when $\mathrm{R}=1.0$ in the $\mathrm{CaO}-\mathrm{SiO}_{2}-\mathrm{Al}_{2} \mathrm{O}_{3}$-based continuous casting mold flux.

(2) The rotating viscometer test results showed that when the $\mathrm{CaF}_{2}$ content in the $\mathrm{CaO}-\mathrm{SiO}_{2}-\mathrm{Al}_{2} \mathrm{O}_{3}-$ based continuous casting mold flux increased within the range of $3-11 \%$, the maintained temperature viscosity of $1300{ }^{\circ} \mathrm{C}$ decreased from 0.854 to $0.241 \mathrm{~Pa} \cdot \mathrm{s}$, the break temperature was 
reduced from 1280 to $1180^{\circ} \mathrm{C}$, and the viscous flow activation energy was reduced from 157.74 to $114.34 \mathrm{~kJ} \cdot \mathrm{mol}^{-1}$. The fluidity of the slag was enhanced.

(3) Molecular dynamics simulations showed that when the $\mathrm{CaF}_{2}$ content increased from $3 \%$ to $11 \%$, the fluorine ions in the slag replaced the oxygen ions in the $\mathrm{Si}-\mathrm{O}-\mathrm{Si}$ structure and $\mathrm{Al}-\mathrm{O}-\mathrm{Al}$ structure. The number of Al-F bonds and $\mathrm{Si}-\mathrm{F}$ bonds that form nonbridging fluorine increased to 287. The maximum number of Si-F-Si bonds, Al-F-Si bonds, and Al-F-Al bonds in the system was only 17. In this range, the $\mathrm{CaF}_{2}$ content was more than that required for the formation of the network. The macromolecular group in the slag system split into numerous small complex anions, which reduced the polymerization degree of the network body and the viscosity of protective slag.

Author Contributions: L.Z. and X.W. conceived and designed the study; Y.X. and Z.P. performed the numerical calculation; H.J. and S.Q. conducted the experiment; R.L. and L.Z. analyzed the experimental data; and X.W. and H.J. wrote the paper.

Funding: This work was financially supported by the National Natural Science Foundation of China, Project Nos, 51404088,51674122 and 51774141.

Acknowledgments: The authors thank Tian Kuo for his help with the experimental tests. They also wish to thank Gao Weimin for guidance on the molecular dynamics program.

Conflicts of Interest: The authors declare no conflict of interest.

\section{References}

1. Long, X.; He, S.; Xu, J.; Huo, X.; Wang, Q. Properties of High Basicity Mold Fluxes for Peritectic Steel Slab Casting. J. Iron Steel Res. Int. 2012, 19, 39-45. [CrossRef]

2. Wang, X.; Kong, L.; Du, F.; Yao, M.; Zhang, X.; Ma, H.; Wang, Z. Mathematical Modeling of Thermal Resistances of Mold Flux and Air Gap in Continuous Casting Mold Based on an Inverse Problem. ISIJ Int. 2016, 56, 803-811. [CrossRef]

3. Wang, P. Study on Fluorine Emitting from Continuous Casting Mould Fluxes. Master's Thesis, Chongqing University, Chongqing, China, 2006. [CrossRef]

4. Hong, X.P. Fluorine and Acid Pollutant within Soil around Three Coal-Rich Areas in China. Ph.D. Thesis, China University Mining and Technology, Beijing, China, 2018. Available online: http://cdmd.cnki.com.cn/ Article/CDMD-11413-1018096977.htm (accessed on 29 March 2018).

5. Park, J.H.; Min, D.J.; Song, H.S. Amphoteric behavior of alumina in viscous flow and structure of $\mathrm{CaO}-\mathrm{SiO}_{2}$ (-MgO)- $\mathrm{Al}_{2} \mathrm{O}_{3}$ slags. Metall. Mater. Trans. B. 2004, 35, 269. [CrossRef]

6. Park, J.H.; Min, D.J. Effect of fluorspar and alumina on the viscous flow of calcium silicate melts containing MgO. J. Non-Cryst. Solids 2004, 337, 150-156. [CrossRef]

7. Ueda, S.; Koyo, H.; Ikeda, T.; Kariya, Y.; Maeda, M. Infrared Emission Spectra of $\mathrm{CaF}_{2}-\mathrm{CaO}_{-} \mathrm{SiO}_{2} \mathrm{Melt}_{\text {ISIJ }}$ Int. 2000, 40, 739-743. [CrossRef]

8. Kim, H.; Sohn, I. Effect of $\mathrm{CaF}_{2}$ and $\mathrm{Li}_{2} \mathrm{O}$ Additives on the Viscosity of $\mathrm{CaO}-\mathrm{SiO}_{2}-\mathrm{Na}_{2} \mathrm{O}$ Slags. ISIJ Int. 2011, 51, 1-8. [CrossRef]

9. Asada, T.; Yamada, Y.; Ito, K. The Estimation of Structural Properties for Molten $\mathrm{CaO}-\mathrm{CaF}_{2}-\mathrm{SiO}_{2}$ System by Molecular Dynamics Simulations. ISIJ Int. 2008, 48, 120-122. [CrossRef]

10. Gao, Q.; Min, Y.; Liu, C.J.; Jiang, M. Structural behavior of $\mathrm{F}^{-}$in mould flux melt of $\mathrm{CaO}-\mathrm{SiO}_{2}-\mathrm{Al}_{2} \mathrm{O}_{3}-\mathrm{Na}_{2} \mathrm{O}-$ $\mathrm{CaF}_{2}$ system. J. Iron Steel Res. Int. 2017, 24, 1152-1158. [CrossRef]

11. Yan, W.; Chen, W.; Yang, Y.; Lippold, C.; McLean, A. Evaluation of $\mathrm{B}_{2} \mathrm{O}_{3}$ as replacement for $\mathrm{CaF}_{2}$ in $\mathrm{CaO}-\mathrm{Al}_{2} \mathrm{O}_{3}$ based mould flux. Ironmak. Steelmak. 2016, 43, 316-323. [CrossRef]

12. Sasaki, Y.; Urata, H.; Ishii, K. Structural Analysis of Molten $\mathrm{Na}_{2} \mathrm{O}-\mathrm{NaF}-\mathrm{SiO}_{2}$ System by Raman Spectroscopy and Molecular Dynamics Simulation. ISIJ Int. 2003, 43, 1897-1903. [CrossRef]

13. Vincent, H.; Bertaut, E.F.; Baur, W.H.; Shannon, R.D. Polyhedral deformations in olivine-type compounds and the crystal structure of $\mathrm{Fe}_{2} \mathrm{SiS}_{4}$ and $\mathrm{Fe}_{2} \mathrm{GeS}_{4}$. Acta Crystallogr. Sect. B Struct. Crystallogr. Cryst. Chem. 1976, 32, 1749-1755. [CrossRef]

14. Hayashi, M.; Nabeshima, N.; Fukuyama, H.; Nagata, K. Effect of Fluorine on Silicate Network for $\mathrm{CaO}-\mathrm{CaF}_{2}-\mathrm{SiO}_{2}$ and $\mathrm{CaO}-\mathrm{CaF}_{2}-\mathrm{SiO}_{2}-\mathrm{FeO}_{\mathrm{x}}$ Glasses. ISIJ Int. 2002, 42, 352-358. [CrossRef] 
15. Niu, Y.J.; You, J.L.; Wang, Y.Y.; Wang, Z.C.; Dai, S.J.; Xu, J.L.; Shen, S.B. Temperature Dependent Raman Spectra and Micro-Structure Study of Cuspidine in Solid and Liquid Phases. Spectrosc. Spectral Anal. 2010, 30, 3228-3231. [CrossRef]

16. Wang, Z.; Tang, P.; Mi, X.X.; Hu, Q.; Lu, Y.F.; Wen, G.H. Effect of w $\left(\left(\mathrm{CaF}_{2}\right)\right)$ on crystallization properties of $\mathrm{CaO}-\mathrm{SiO}_{2}-\mathrm{Al}_{2} \mathrm{O}_{3}$ based mold fluxes. Iron Steel. 2018, 53, 38-44. [CrossRef]

17. Wu, T. Study on Microstructure and Macroproperty of Mould Fluxes with Low-Reactivity. Ph.D. Thesis, Chongqing University, Chongqing, China, 2017.

18. Yang, B.J. Research on Inclusions Absorbability of Continuous Casting Mold Powder. Master's Thesis, University of Science and Technology Liaoning, Anshan, China, 2006. Available online: http://cdmd.cnki. com.cn/Article/CDMD-10146-2007047863.htm (accessed on 24 July 2007).

19. Huang, S.P.; Jiang, G.C.; You, J.L.; Yoshida, F.; Xu, K.D. The ionic properties of $\mathrm{CaSiO}_{3}$ melt. Metall. Mater. Trans. B 2000, 31, 1241-1245. [CrossRef]

20. Delaye, J.; Louis-Achille, V.; Ghaleb, D. Modeling oxide glasses with Born-Mayer-Huggins potentials: Effect of composition on structural changes. J. Non-Cryst. Solids 1997, 210, 232-242. [CrossRef]

21. Shimoda, K.; Saito, K. Detailed Structure Elucidation of the Blast Furnace Slag by Molecular Dynamics Simulation. ISIJ Int. 2007, 47, 1275-1279. [CrossRef]

22. Meng, Y.; Thomas, B.G. Simulation of Microstructure and Behavior of Interfacial Mold Slag Layers in Continuous Casting of Steel. ISIJ Int. 2006, 46, 660-669. [CrossRef]

23. Gao, E.Z.; Wang, W.L.; Zhang, L. Effect of alkaline earth metal oxides on the viscosity and structure of the $\mathrm{CaO}-\mathrm{Al}_{2} \mathrm{O}_{3}$ based mold flux for casting high-al steels. J. Non-Cryst. Solids 2017, 473, 79-86. [CrossRef]

24. Gao, J.X.; Wen, G.H.; Huang, T.; Tang, P.; Liu, Q. Effects of the composition on the structure and viscosity of the $\mathrm{CaO}-\mathrm{SiO}_{2}$-based mold flux. J. Non-Cryst. Solids 2016, 435, 33-39. [CrossRef]

25. Gan, L.; Lai, C.B.; Xiong, H.H. Non-Arrhenius Viscosity Models for Molten Silicate Slags with Constant Pre-Exponential Parameter: A Comparison to Arrhenius Model. High Temp. Mater. Process. 2016, 35, 261-267. [CrossRef]

26. Kim, G.H.; Sohn, I. Influence of $\mathrm{Li}_{2} \mathrm{O}$ on the Viscous Behavior of $\mathrm{CaO}-\mathrm{Al}_{2} \mathrm{O}_{3}-12$ mass $\% \mathrm{Na}_{2} \mathrm{O}-12$ mass $\%$ $\mathrm{CaF}_{2}$ Based Slags. ISIJ Int. 2012, 52, 68-73. [CrossRef]

27. Lee, S.; Min, D.J. Anionic effect of chloride, fluoride, and sulfide ions on the viscosity of slag melt. J. Am. Ceram. Soc. 2017, 100, 2543-2552. [CrossRef]

28. Feng, C.; Chu, M.S.; Tang, J.; Tang, Y.T.; Liu, Z.G. Effect of $\mathrm{CaO} / \mathrm{SiO}_{2}$ and $\mathrm{Al}_{2} \mathrm{O}_{3}$ on Viscous Behaviors of the Titanium-Bearing Blast Furnace Slag. Steel Res. Int. 2016, 87, 1274-1283. [CrossRef]

29. Park, J.H.; Ko, K.Y.; Kim, T.S. Influence of $\mathrm{CaF}_{2}$ on the Viscosity and Structure of Manganese Ferroalloys Smelting Slags. Metall. Mater. Trans. B 2014, 46, 741-748. [CrossRef]

30. Dai, X.; He, J.; Bai, J.; Huang, Q.; Wen, X.D.; Xie, L.; Luo, K.; Zhang, J.; Li, W.; Du, S.Y. Ash Fusion Properties from Molecular Dynamics Simulation: Role of the Ratio of Silicon and Aluminum. Energy Fuels 2016, 30, 2407-2413. [CrossRef]

31. Matsui, M. Molecular dynamics simulation of structures, bulk moduli, and volume thermal expansivities of silicate liquids in the system $\mathrm{CaO}-\mathrm{MgO}-\mathrm{Al}_{2} \mathrm{O}_{3}-\mathrm{SiO}_{2}$. Geophys. Res. Lett. 1996, 23, 395-398. [CrossRef]

32. Wang, X.J.; Wu, B.B.; Zhu, L.G.; Fan, Y.P.; Tian, K. Study on Rheological Properties of Fluorine-free Continuous Casting Mould Powder. Iron Steel Vanadium Titan. 2017, 38, 135-139. [CrossRef]

(C) 2019 by the authors. Licensee MDPI, Basel, Switzerland. This article is an open access article distributed under the terms and conditions of the Creative Commons Attribution (CC BY) license (http://creativecommons.org/licenses/by/4.0/). 